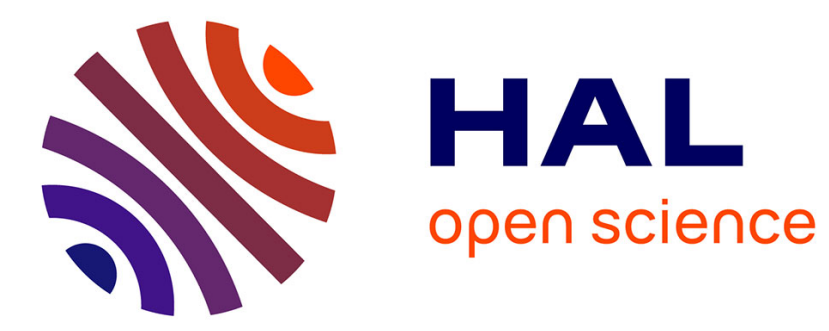

\title{
Risk factors for injury accidents among moped and motorcyle riders
}

\author{
A. Moskal, Jl Martin, Bernard Laumon
}

\section{To cite this version:}

A. Moskal, Jl Martin, Bernard Laumon. Risk factors for injury accidents among moped and motorcyle riders. Accident Analysis \& Prevention, 2010, 15p. hal-00543304

\section{HAL Id: hal-00543304 \\ https://hal.science/hal-00543304}

Submitted on 6 Dec 2010

HAL is a multi-disciplinary open access archive for the deposit and dissemination of scientific research documents, whether they are published or not. The documents may come from teaching and research institutions in France or abroad, or from public or private research centers.
L'archive ouverte pluridisciplinaire HAL, est destinée au dépôt et à la diffusion de documents scientifiques de niveau recherche, publiés ou non, émanant des établissements d'enseignement et de recherche français ou étrangers, des laboratoires publics ou privés. 


\title{
Risk factors for injury accidents among moped and motorcycle riders
}

\author{
Aurélie Moskal $^{\mathrm{a}}$, Jean-Louis Martin ${ }^{\mathrm{a}, \star}$, Bernard Laumon $^{\mathrm{a}}$ \\ a UMRESTTE, UMR T9405, INRETS, Université de Lyon, F-69003, France
}

\begin{abstract}
* Corresponding author at: UMRESTTE- INRETS, 25 Avenue François Mitterrand, 69675 Bron Cedex, France. Tel.: +33 4721425 22; fax: +33 472142520

E-mail addresses: moskala@fellows.iarc.fr (A. Moskal), jean-louis.martin@inrets.fr (J.L. Martin), bernard.laumon@inrets.fr (B.Laumon)
\end{abstract}

\begin{abstract}
Objective: to study and quantify the effect of factors related to the riders of powered twowheelers on the risk of injury accident involvement.

Methodology: based on national data held by the police from 1996 to 2005, we conducted a case-control study with responsibility for the accident as the event of interest. We estimated the odds ratios for accident responsibility. Making the hypothesis that the non-responsible riders in the study are representative of all the riders on the road, we thus identified risk factors for being responsible for injury accidents. The studied factors are age, gender, helmet wearing, alcohol consumption, validity of the subject's driving licence and for how long it has been held, the trip purpose and the presence of a passenger on the vehicle. Moped and motorcycle riders are analyzed separately, adjusting for the main characteristics of the accident.

Results: for both moped and motorcycle riders, being male, not wearing a helmet, exceeding the legal limit for alcohol and travelling for leisure purposes increased the risk of accident involvement. The youngest and oldest users had a greater risk of accident involvement. The largest risk factor was alcohol, and we identified a dose-effect relationship between alcohol consumption and accident risk, with an estimated odds ratio of over 10 for motorcycle and moped riders with a BAC of $2 \mathrm{~g} / \mathrm{l}$ or over. Among motorcycle users, riders without a licence had twice the risk of being involved in an accident than those holding a valid licence. However, the number of years the rider had held a licence reduced the risk of accident involvement. One difference between moped and motorcycle riders involved the presence of a passenger on the vehicle: while carrying a passenger increased the risk of being responsible for the accident among moped riders, it protected against this risk among motorcycle riders.
\end{abstract}

Conclusion: this analysis of responsibility has identified the major factors contributing to excess risk of injury accidents, some of which could be targeted by prevention programmes.

Keywords: powered two wheeler, rider, injury, risk factors 


\section{Introduction}

In France, as in other industrialized countries, although the users of powered two-wheelers (PTW) represent less than $2 \%$ of the vehicles on the road, they account for a very high proportion of the individuals who are injured and killed on the roads (NHTSA 2006; ONISR 2007; SafetyNet 2008). In 2006, in Europe, this group represented $22 \%$ of the total number of road traffic accident fatalities (SafetyNet 2008). Thus, considering the vehicles that were on the road in 2005 , the fatality risk for PTW riders was greater by a factor of 7 for motorcycle riders and a factor of 3 for moped riders, compared to car riders (ONISR 2007). A specific feature of PTW riders, in addition to their vulnerability, is the high risk of accident involvement, which is several times higher than for motorists (Horswill and Helman 2003; Langley et al. 2000). This risk may be influenced by several individual and environmental factors that apply to PTW users (Lardelli-Claret et al. 2005).

In epidemiology, the type of study design which is the most used in order to investigate the above factors and estimate accident risks is the case-control study, in which the cases consist of accident-involved PTW riders and the controls consist of a group of non accident-involved PTW riders, selected at random from all the PTWs on the roads, for example at the same times and locations the accidents occurred (Evans 2004). In the case of a rare event, the estimated odds ratios for each factor provide good estimations of the relative risks of accident involvement. As studies of this type are difficult to perform, researchers have developed techniques that make it possible to estimate accident risks from data that refer exclusively to accident-involved subjects. Such data, which are frequently available, contain information on the accident factors which may allow us to evaluate the primary safety issues (Chandraratna and Stamatiadis 2009). These methods use a group of accident-involved riders as an exposure metric, making the hypothesis that the controls are representative of both riders on the road and accident-involved riders by simple virtue of their presence on the road.

The aim of this study is to quantify the effect of different factors that are related to PTW riders on accident risk by using a case-control study with accident responsibility as the event.

\section{Material and methods}

This analysis is based on the exploitation of national data from the French police from 1996 to 2005, i.e. injury accident reports or Bulletins d'Analyse des Accidents corporels de la Circulation (BAAC) (ONISR 2007). The BAACs are the computerized version of the accident reports which the police have the obligation to draw up for all personal injury road traffic accidents occurring in France. Each accident report provides a precise description of the circumstances of the accident and the characteristics of the vehicles and of the users involved.

We have conducted a case-control study and investigated the risk factors for being responsible for an accident among PTW riders. We have made the hypothesis that our controls, nonresponsible riders, are a representative sample of all riders on the road. Thus, the prevalences of the different risk factors in this control group provide a picture of the exposure of the population on 
the road to these factors. With this hypothesis, our analysis amounts to comparing the riders on the road to the riders who are responsible for an accident. The studied event is rare and the estimated odds ratios for each factor provide good estimations of the relative risks of accident involvement. The methodology used here has been presented in the contract report for the SAM survey "Psychotropic drugs and fatal accidents" ("Stupéfiants et Accidents Mortels" (Laumon et al. 2009).

\subsection{Determining responsibility}

We determined accident responsibility for each rider by using the method developed by Robertson and Drummer (Robertson and Drummer 1994) which has been adapted to suit the data available in the BAAC. This systematic determination method calculates a responsibility score based on information that is used by the police in their procedures.

To begin with, each crash-involved rider is considered to be responsible. Several classes of factors that can attenuate this responsibility are considered: the state of the road, that of the vehicle, traffic conditions, the type of accident, compliance with the Highway Code and the complexity of the driving task. Two factors are of prime importance when determining responsibility: whether a rider has committed one or more Highway Code violations, and whether, in the case of accidents involving two or more vehicles, the police considered the rider to be responsible. Factors that relate to the rider such as age, gender and alcohol consumption are not considered when calculating responsibility.

This procedure for determining responsibility assigns a final score to each rider who is then classified as responsible, partly responsible or not responsible. We have decided to group partly responsible riders together with fully responsible riders. We consider that riders having some responsibility in the accident occurrence are the "cases", while riders without any responsibility can be considered as good "controls", i.e. riders who were involved in the accident as a result of "bad luck", and as such representative of riders "on the road".

\subsection{Validation of ascribed responsibility}

A group of experts in accident studies evaluated the responsibility of the riders in 3,024 fatal accidents involving two or more vehicles based on the accident reports (Laumon et al. 2005; Laumon et al. 2009). The agreement between this "expert ascribed responsibility" and the responsibility determined by the Robertson and Drummer algorithm was evaluated and found to be adequate (Kappa test $=0.6795 \% \mathrm{Cl}(0.65-0.70)$.

\subsection{Analysis strategy}

For this study, we selected all the PTW riders present in the BAAC files who were involved in an injury accident between 1996 and 2005, irrespective of accident severity. We calculated the responsibility of the riders for the accidents, the riders who were classified as responsible or partly responsible forming the cases and the non responsible riders the control group. 
We compared the distribution of the different characteristics of the PTW riders according to their accident responsibility. The factors that were taken into account were age, gender, helmet wearing, alcohol consumption, whether the individual held a driving licence and if so for how long he/she had done so, the trip purpose and whether the vehicle was carrying a passenger. We estimated the non adjusted and adjusted relative risks of being responsible for the accident. We used logistic regression models to do this. We estimated the raw and adjusted odds ratios for each factor of interest and calculated the corresponding 95\% confidence intervals. The adjustment factors related to the accident and its circumstances: the day (weekday or weekend), time of day ([22h to $7 \mathrm{~h}$ [ or [7h to $22 \mathrm{~h}[$ ), month and year of the accident, location of the accident (Non-built-up area, Built-up area), the type of road (PTW on its own, PTW with pedestrian, PTW with other vehicle and no pedestrian) and the type of accident (Motorway, Trunk road, County road, Street, Other).

The factors were included in the multivariate analysis irrespective of whether or not they achieved significance.

We conducted separate analyses for moped and motorcycle riders, thereby anticipating potential differences between the two modes: the age at which it is possible to ride a vehicle, the type of training required to drive it, different use of the vehicle. As several PTW riders may be involved in the same accident, the number of PTW riders studied exceeded the number of accidents.

We used different age classes for moped and motorcycle riders in order to give more importance to 14-15 year-old moped riders. The large number of riders and the long period covered by our study allows us to consider age in a precise manner using 13 age classes and enables us to study the relationship between age and accident responsibility in a precise manner. The variables "validity of motorcycle driving licence" and "length of time the licence has been held" are only valid for motorcyclists as no licence exists for mopeds.

\section{Results}

The analysis covered 362,547 PTW riders involved in 352,177 accidents during the study period. For both moped and motorcycle riders, three-quarters of the accidents took place on a weekday and 9 out of 10 during the daytime (Table 1). The main differences between moped and motorcycle riders related to the accident location in terms of the type of road and whether it occurred inside or outside a built-up area. One in four motorcycle accidents took place outside a built-up area, and moped accidents tended to occur more in built-up areas. The proportions of accidents occurring on trunk roads and motorways were very different for moped and motorcycle riders. 
Table 1: The characteristics of the accidents involving PTW riders according to the type of PTW, BAAC1996-2005

\begin{tabular}{|c|c|c|c|c|c|}
\hline & \multirow[t]{2}{*}{ Studied factors } & \multicolumn{2}{|c|}{ Moped riders } & \multicolumn{2}{|c|}{ Motocycle riders } \\
\hline & & $\mathrm{N}=181,319$ & $\%$ & $\mathrm{~N}=181,228$ & $\%$ \\
\hline \multirow[t]{2}{*}{ Day } & Week day & 137,510 & 75.8 & 134,895 & 74.4 \\
\hline & Week-end & 43,809 & 24.2 & 46,333 & 25.6 \\
\hline \multirow[t]{2}{*}{ Time of day } & [22h to $7 \mathrm{~h}[$ & 18,897 & 10.4 & 19,595 & 10.8 \\
\hline & [7h to $22 \mathrm{~h}[$ & 162,422 & 89.6 & 161,633 & 89.2 \\
\hline \multirow[t]{12}{*}{ Month } & January & 12,539 & 6.9 & 10,266 & 5.7 \\
\hline & February & 11,501 & 6.3 & 10,179 & 5.6 \\
\hline & March & 14,415 & 8.0 & 14,465 & 8.0 \\
\hline & April & 14,082 & 7.8 & 14,578 & 8.0 \\
\hline & May & 15,688 & 8.7 & 17,503 & 9.7 \\
\hline & June & 17,635 & 9.7 & 19,602 & 10.8 \\
\hline & July & 16,222 & 8.9 & 18,075 & 10.0 \\
\hline & August & 14,178 & 7.8 & 15,498 & 8.6 \\
\hline & September & 17,278 & 9.5 & 18,583 & 10.3 \\
\hline & October & 18,810 & 10.4 & 17,622 & 9.7 \\
\hline & November & 15,706 & 8.7 & 13,665 & 7.5 \\
\hline & December & 13,265 & 7.3 & 11,192 & 6.2 \\
\hline \multirow[t]{10}{*}{ Year } & 1996 & 20,334 & 11.2 & 16,418 & 9.1 \\
\hline & 1997 & 20,629 & 11.4 & 18,215 & 10.1 \\
\hline & 1998 & 20,036 & 11.1 & 18,369 & 10.1 \\
\hline & 1999 & 20,016 & 11.0 & 19,517 & 10.8 \\
\hline & 2000 & 19,757 & 10.9 & 19,694 & 10.9 \\
\hline & 2001 & 18,667 & 10.3 & 19,794 & 10.9 \\
\hline & 2002 & 16,656 & 9.2 & 18,248 & 10.1 \\
\hline & 2003 & 15,980 & 8.8 & 16,208 & 8.9 \\
\hline & 2004 & 15,560 & 8.6 & 16,203 & 8.9 \\
\hline & 2005 & 13,684 & 7.5 & 18,562 & 10.2 \\
\hline \multirow[t]{2}{*}{ Location } & Non-built-up area & 26,178 & 14.4 & 45,981 & 25.4 \\
\hline & Built-up area & 155,141 & 85.6 & 135,247 & 74.6 \\
\hline \multirow[t]{3}{*}{ Type of accident } & PTW on its own & 20,206 & 11.1 & 30,350 & 16.7 \\
\hline & PTW with pedestrian & 10,395 & 5.7 & 10,860 & 6.0 \\
\hline & $\begin{array}{l}\text { PTW with other vehicle and no } \\
\text { pedestrian }\end{array}$ & 150,718 & 83.1 & 140,018 & 77.3 \\
\hline \multirow[t]{5}{*}{ Type of road } & Motorway & 210 & 0.1 & 9,367 & 5.2 \\
\hline & Trunk road & 16,504 & 9.1 & 25,968 & 14.3 \\
\hline & County road & 48,958 & 27.0 & 49,363 & 27.2 \\
\hline & Street & 97,271 & 53.6 & 87,288 & 48.2 \\
\hline & Other & 18,376 & 10.1 & 9,242 & 5.1 \\
\hline
\end{tabular}

Table 2 sets out the main characteristics of the riders according to type of PTW. 
Table 2: Characteristics of the accident-involved PTW riders according to the type of PTW, BAAC 1996-2005

\begin{tabular}{|c|c|c|c|c|c|}
\hline \multicolumn{2}{|c|}{ Studied factors } & \multicolumn{2}{|c|}{ Moped riders } & \multicolumn{2}{|c|}{ Motorcycle riders } \\
\hline & & $\mathrm{N}=181,319$ & $\%$ & $\mathrm{~N}=181,228$ & $\%$ \\
\hline \multirow[t]{2}{*}{ Gender } & Male & 153,728 & 84.8 & 171,544 & 94.7 \\
\hline & Female & 27,591 & 15.2 & 9,684 & 5.3 \\
\hline \multirow[t]{3}{*}{ Helmet } & Yes & 151,436 & 83.5 & 160,853 & 88.8 \\
\hline & No & 7,512 & 4.1 & 2,744 & 1.5 \\
\hline & Not known & 22,371 & 12.3 & 17,631 & 9.7 \\
\hline \multirow[t]{14}{*}{ Âge } & $0-13$ years & 945 & 0.5 & ,- & - \\
\hline & $14-15$ years & 31,013 & 17.1 & 710 & 0.4 \\
\hline & $16-17$ years & 53,917 & 29.7 & 7,171 & 4.0 \\
\hline & $18-20$ years & 35,393 & 19.5 & 7,302 & 4.0 \\
\hline & 21-24 years & 16,846 & 9.3 & 29,713 & 16.4 \\
\hline & $25-29$ years & 10,711 & 5.9 & 40,131 & 22.1 \\
\hline & $30-34$ years & 7,255 & 4.0 & 31,165 & 17.2 \\
\hline & $35-39$ years & 5,812 & 3.2 & 23,663 & 13.1 \\
\hline & 40-44 years & 4,665 & 2.6 & 17,670 & 9.8 \\
\hline & $45-54$ years & 6,984 & 3.9 & 18,006 & 9.9 \\
\hline & $55-64$ years & 3,213 & 1.8 & 3,740 & 2.1 \\
\hline & $65-74$ years & 2,077 & 1.1 & 804 & 0.4 \\
\hline & 75 years and over & 1,183 & 0.7 & 211 & 0.1 \\
\hline & Not known & 1,305 & 0.7 & 942 & 0.5 \\
\hline Blood & Not measured & 40,530 & 22.4 & 30,434 & 16.8 \\
\hline alcohol & Measured, result not known & 18,916 & 10.4 & 23,708 & 13.1 \\
\hline \multirow[t]{5}{*}{ level } & $<0,5 \mathrm{~g} / \mathrm{l}$ & 115,310 & 63.6 & 121,258 & 66.9 \\
\hline & {$[0,5-0,8[\mathrm{~g} / \mathrm{l}$} & 490 & 0.3 & 657 & 0.4 \\
\hline & {$[0,8-1,2[\mathrm{~g} / \mathrm{l}$} & 868 & 0.5 & 1,099 & 0.6 \\
\hline & {$[1,2-2,0[\mathrm{~g} / \mathrm{l}$} & 2,235 & 1.2 & 2,317 & 1.3 \\
\hline & $2 \mathrm{~g} / \mathrm{l}$ et + & 2,970 & 1.6 & 1,755 & 1.0 \\
\hline Validity of & Not known & ,- & - & 5,586 & 3.1 \\
\hline driving & Time held not known & ,- & - & 9,340 & 5.2 \\
\hline \multirow[t]{4}{*}{ licence } & Not valid & ,- & - & 5,788 & 3.2 \\
\hline & Valid, held for<2years & ,- & - & 45,144 & 24.9 \\
\hline & Valid, held for [2-5[years &,- & - & 37,781 & 20.8 \\
\hline & Valid, held for $\geq 5$ years & ,- & - & 77,589 & 42.8 \\
\hline Trip & Home-to-work & 23,358 & 12.9 & 36,414 & 20.1 \\
\hline \multirow[t]{5}{*}{ purpose } & Home-to-school & 12,062 & 6.6 & 1,526 & 0.8 \\
\hline & Leisure (shopping, purchases) & 103,138 & 56.9 & 86,556 & 47.8 \\
\hline & Other & 27,400 & 15.1 & 32,372 & 17.9 \\
\hline & At work & 12,108 & 6.7 & 20,524 & 11.3 \\
\hline & Not known & 3,253 & 1.8 & 3,836 & 2.1 \\
\hline Number of & None & 157,685 & 87.0 & 158,927 & 87.7 \\
\hline passengers & 1 or more & 23,634 & 13.0 & 22,301 & 12.3 \\
\hline
\end{tabular}

The proportion of females was higher among moped riders than among motorcycle riders. The sex ratio was 5.5 among moped riders and 17.7 among motorcycle riders. With regard to helmet wearing, the proportion of unhelmeted riders was higher among the moped riders than the motorcycle riders: in the cases where this factor was known, $95.3 \%$ of moped riders were helmeted compared with $98.8 \%$ of motorcyclists.

945 moped riders and 710 motorcycle riders were involved in an accident as a rider when they were under legal age which is respectively 14 and 16 years old. Almost half the crash-involved moped riders were between 14 and 17 years of age (46.8\%). Among motorcyclists, $16-17$ year-olds 
accounted for $4 \%$ of the casualties. Seven out of ten crash-involved motorcyclists were between 21 and 39 years old.

The blood alcohol level of $67.2 \%$ of the moped riders and $70.2 \%$ of the motorcyclists was measured and recorded in the BAACs. In those cases where blood alcohol level was measured and the result known, the percentage of riders who were over the legal limit was higher among the moped riders (5.4\%) than the motorcyclists (4.6\%).

Most of the accidents involving PTW riders occurred during leisure trips. Trips made while at work accounted for $19.6 \%$ of moped riders' accidents and $31.4 \%$ of motorcycle accidents. In $7 \%$ of cases, the motorcycle riders were involved in an accident during a home-to-school trip.

The percentage of moped riders and motorcyclists who were involved in an accident while carrying a passenger was the same (13\%). The number of PTW riders who were involved in an accident while carrying more than one passenger was very small $(0.1 \%)$.

Information regarding the driving licence of motorcyclists and its validity was known for almost all the crash-involved riders (97\%). Riders without a driving licence who were involved in an accident accounted for $3.2 \%$ of cases. The length of time they held their licence was available for $92 \%$ of the crash-involved riders. Among the crash-involved riders with a valid driving licence, $48.3 \%$ had held their licence for at least five years. Novice riders, that is to say those who had held their licence for less than 2 years accounted for $28.1 \%$ of cases.

\subsection{Risk factors for crash involvement among moped riders}

Of the 181,319 moped riders, 105,560 , i.e. $58.2 \%$, were responsible for their accident. Table 3 shows the raw and adjusted odds ratios for injury accident involvement among moped riders. 
Table 3: Risk factors for accident involvement among moped riders: raw and adjusted odds ratios, BAAC 1996-2005

\begin{tabular}{|c|c|c|c|c|c|c|c|}
\hline \multirow{2}{*}{ Studied factors } & & \multicolumn{2}{|c|}{ Responsible } & \multicolumn{2}{|c|}{ Not responsible } & \multirow{2}{*}{$\mathrm{OR}_{\text {raw }}(95 \% \mathrm{Cl})$} & \multirow{2}{*}{$\mathrm{OR}_{\mathrm{adj} .}(95 \% \mathrm{Cl})^{\mathrm{a}}$} \\
\hline & & $\mathrm{N}=105,560$ & $\%$ & $\mathrm{~N}=75,759$ & $\%$ & & \\
\hline \multirow[t]{2}{*}{ Gender } & Male & 91,059 & 86.3 & 62,669 & 82.7 & $1.31(1.28-1.35)$ & $1.26(1.23-1.30)$ \\
\hline & Female & 14,501 & 13.7 & 13,090 & 17.3 & 1 & 1 \\
\hline \multirow[t]{14}{*}{ Âge } & $0-13$, years & 686 & 0.6 & 259 & 0.3 & $1.83(1.58-2.13)$ & $1.89(1.61-2.22)$ \\
\hline & 14-15,years & 18,725 & 17.7 & 12,288 & 16.2 & $1.05(1.00-1.11)$ & $1.34(1.26-1.42)$ \\
\hline & 16-17,years & 30,970 & 29.3 & 22,947 & 30.3 & $0.93(0.89-0.98)$ & $1.21(1.14-1.28)$ \\
\hline & 18-20,years & 20,524 & 19.4 & 14,869 & 19.6 & $0.95(0.91-1.00)$ & $1.16(1.09-1.23)$ \\
\hline & 21-24,years & 9,717 & 9.2 & 7,129 & 9.4 & $0.94(0.89-1.00)$ & $1.09(1.02-1.16)$ \\
\hline & 25-29, years & 6,137 & 5.8 & 4,574 & 6.0 & $0.93(0.87-0.99)$ & $1.00(0.93-1.07)$ \\
\hline & 30-34,years & 4,289 & 4.1 & 2,966 & 3.9 & 1 & 1 \\
\hline & 35-39, years & 3,479 & 3.3 & 2,333 & 3.1 & $1.03(0.96-1.11)$ & $0.99(0.92-1.08)$ \\
\hline & 40-44,years & 2,749 & 2.6 & 1,916 & 2.5 & $0.99(0.92-1.07)$ & $0.92(0.84-1.00)$ \\
\hline & 45-54,years & 3,873 & 3.7 & 3,111 & 4.1 & $0.86(0.81-0.92)$ & $0.85(0.79-0.92)$ \\
\hline & 55-64,years & 1,762 & 1.7 & 1,451 & 1.9 & $0.84(0.77-0.91)$ & $0.87(0.79-0.95)$ \\
\hline & 65-74,years & 1,188 & 1.1 & 889 & 1.2 & $0.92(0.84-1.02)$ & $1.04(0.93-1.15)$ \\
\hline & 75 ,years, and,over & 726 & 0.7 & 457 & 0.6 & $1.10(0.97-1.25)$ & $1.30(1.13-1.48)$ \\
\hline & Not,known & 735 & 0.7 & 570 & 0.8 & $0.89(0.79-1.00)$ & $0.91(0.80-1.04)$ \\
\hline \multirow[t]{3}{*}{ Helmeted } & Yes & 86,672 & 82.1 & 64,764 & 85.5 & 1 & 1 \\
\hline & No & 5,548 & 5.3 & 1,964 & 2.6 & $2.11(2.00-2.22)$ & $1.81(1.71-1.91)$ \\
\hline & Not,known & 13,340 & 12.6 & 9,031 & 11.9 & $1.10(1.07-1.14)$ & $1.08(1.04-1.11)$ \\
\hline \multirow[t]{7}{*}{ Blood alcohol level } & Not,found & 23,478 & 22.2 & 17,052 & 22.5 & $1.08(1.06-1.10)$ & $1.06(1.03-1.08)$ \\
\hline & Found,,result,unknown & 11,371 & 10.8 & 7,545 & 10.0 & $1.18(1.15-1.22)$ & $1.08(1.02-1.15)$ \\
\hline & $<0,5, \mathrm{~g} / \mathrm{l}$ & 64,621 & 61.2 & 50,689 & 66.9 & 1 & 1 \\
\hline & {$[0,5-0,8[\mathrm{~g} / \mathrm{l}$} & 400 & 0.4 & 90 & 0.1 & $3.49(2.77-4.38)$ & $2.71(2.12-3.45)$ \\
\hline & {$[0,8-1,2[\mathrm{~g} / \mathrm{l}$} & 781 & 0.7 & 87 & 0.1 & $7.04(5.64-8.79)$ & $5.47(4.35-6.89)$ \\
\hline & {$[1,2-2,0[\mathrm{~g} / \mathrm{l}$} & 2,090 & 2.0 & 145 & 0.2 & $11.3(9.55-13.4)$ & $7.95(6.67-9.46)$ \\
\hline & 2,g/l,et,+ & 2,819 & 2.7 & 151 & 0.2 & $14.6(12.4-17.2)$ & $10.3(8.67-12.2)$ \\
\hline \multirow[t]{6}{*}{ Trip purpose } & Home-to-work & 11,763 & 11.1 & 11,595 & 15.3 & $0.68(0.67-0.70)$ & $0.80(0.77-0.82)$ \\
\hline & Home-to-school & 6,207 & 5.9 & 5,855 & 7.7 & $0.68(0.66-0.71)$ & $0.84(0.80-0.87)$ \\
\hline & Leisure & 62,736 & 59.4 & 40,402 & 53.3 & 1 & 1 \\
\hline & Other & 16,208 & 15.3 & 11,192 & 14.8 & $0.93(0.91-0.96)$ & $1.02(0.99-1.05)$ \\
\hline & At,work & 6,750 & 6.4 & 5,358 & 7.1 & $0.81(0.78-0.84)$ & $1.00(0.96-1.05)$ \\
\hline & Unknown & 1,896 & 1.8 & 1,357 & 1.8 & $0.90(0.84-0.97)$ & $0.88(0.81-0.95)$ \\
\hline Number of & None & 90,776 & 86.0 & 66,909 & 88.3 & 1 & 1 \\
\hline passengers & 1,or,more & 14,784 & 14.0 & 8,850 & 11.7 & $1.23(1.20-1.27)$ & $1.16(1.12-1.20)$ \\
\hline
\end{tabular}

${ }^{a}$ Analyses adjusted for the time of day, the day, the month and the year of the accident, and the location, type of road and type of accident.

Male moped riders had a higher risk of injury accident involvement than female (Table 3). Unhelmeted riders had twice the risk of being involved in an accident than helmeted riders. Agerelated risks had a U-shaped distribution: the risk of accident involvement was at its highest for the extreme age groups (those aged 14 and driving illegally and those aged over 75) in comparison with the reference group of 30-34 year-olds.

We observed a very high accident-involvement risk for riders with a blood alcohol level above the legal limit of $0.5 \mathrm{~g} / \mathrm{l}$. We also observed a dose-response effect for the risk of accidentinvolvement in the case of alcohol consumption. This association was slightly attenuated when we controlled for other factors, but it still remained significant. The risk for riders with a blood alcohol level of between 0.5 and $0.8 \mathrm{~g} / \mathrm{l}$ was 2.71 times that for riders with an alcohol level of less than 0.5 $\mathrm{g} / \mathrm{l}$. The risk was more than 6 times higher for riders with a blood alcohol level of over $0.8 \mathrm{~g} / \mathrm{l}$. 
With regard to trip purpose, moped riders had a higher risk of being involved in an accident when making a leisure trip than on a home-to-work or a home-to-school trip.

Moped riders carrying passengers had a higher accident risk than those without a passenger.

\subsection{Risk factors for accident involvement among motorcycle riders}

Of the 181,228 motorcyclists, 96,907 , i.e. $53.5 \%$, were responsible for their accident. Table 4 sets out the raw and adjusted odds ratios for injury accident involvement among motorcycle riders. Male gender and not wearing a helmet increased the risk of being responsible for an injury accident, i.e. the risk of being involved in an injury accident. Accident risk according to rider age had a U-shaped distribution: riders of under 16 years of age, driving illegally, had twice the risk of accident involvement than the reference group of 30-34 year-olds. The risk of being involved in an accident fell with age in the case of riders under 45 years of age, with a 45-54 year-old age group having the lowest estimated risk. Risk increased for riders over 65 years of age.

We observed a high risk of injury accidents among riders who had consumed alcohol whose blood alcohol level was equal to or over the legal limit of $0.5 \mathrm{~g} / \mathrm{l}$. As for moped riders, we observed a dose-response effect for risk in the case of alcohol consumption which reached a raw odds ratio of 20 for motorcycle riders with a blood alcohol level of $2 \mathrm{~g} / \mathrm{l}$ and over. This association between alcohol consumption and accident risk was attenuated after adjustment for the other factors, but the estimated risks were still very high: compared with riders who were not over the legal limit, riders with an illegal blood alcohol level of between 0.5 and $0.8 \mathrm{~g} / \mathrm{l}$ were at 3.7 times more risk of being involved in an accident, and beyond this level their risk increased with alcohol dose. Riders with more than $2 \mathrm{~g} / \mathrm{l}$ of alcohol in their blood had 11 times the risk of being responsible for an accident than riders with less than $0.5 \mathrm{~g} / \mathrm{l}$.

With regard to the driving licence, riders without a licence had twice the risk of being involved in an accident than riders with a valid licence. We also observed a reduction in accident risk in the case of riders according to the number of years they had held their licence.

With regard to trip purpose, riders had a higher risk of being involved in an accident when making a leisure trip than on a home-to-work or a home-to-school trip.

Finally, motorcycle riders carrying passengers had less risk of being involved in an accident than riders travelling alone: after adjustment, the estimated risk was 0.92 . 
Table 4: Risk factors for accident involvement among motorcycle riders: raw and adjusted odds ratios, BAAC 1996-2005

\begin{tabular}{|c|c|c|c|c|c|c|c|}
\hline \multirow{2}{*}{ Studied factors } & & \multicolumn{2}{|c|}{ Responsible } & \multicolumn{2}{|c|}{ Not responsible } & \multirow{2}{*}{$\mathrm{OR}_{\text {raw }}(95 \% \mathrm{Cl})$} & \multirow{2}{*}{$\mathrm{OR}_{\mathrm{adj} \cdot}(95 \% \mathrm{Cl})^{\mathrm{a}}$} \\
\hline & & $\mathrm{N}=96,907$ & $\%$ & $\mathrm{~N}=84,321$ & $\%$ & & \\
\hline \multirow[t]{2}{*}{ Gender } & Male & 91,993 & 94.9 & 79,551 & 94.3 & $1.12(1.08-1.17)$ & $1.07(1.02-1.12)$ \\
\hline & Female & 4,914 & 5.1 & 4,770 & 5.7 & 1 & \\
\hline \multirow[t]{13}{*}{ Âge } & $0-15$, years & 486 & 0.5 & 224 & 0.3 & $1.95(1.66-2.30)$ & $2.06(1.73-2.46)$ \\
\hline & $16-17$,years & 4,105 & 4.2 & 3,066 & 3.6 & $1.20(1.14-1.27)$ & $1.35(1.27-1.44)$ \\
\hline & 18-20,years & 4,248 & 4.4 & 3,054 & 3.6 & 1.25 (1.19-1.32) & $1.37(1.29-1.45)$ \\
\hline & 21-24,years & 16,412 & 16.9 & 13,301 & 15.8 & $1.11(1.07-1.14)$ & $1.17(1.13-1.22)$ \\
\hline & $25-29$, years & 21,621 & 22.3 & 18,510 & 22.0 & $1.05(1.02-1.08)$ & $1.09(1.06-1.13)$ \\
\hline & $30-34$,years & 16,413 & 16.9 & 14,752 & 17.5 & 1 & \\
\hline & $35-39$,years & 12,322 & 12.7 & 11,341 & 13.4 & $0.98(0.94-1.01)$ & $0.96(0.93-1.00)$ \\
\hline & $40-44$,years & 9,064 & 9.4 & 8,606 & 10.2 & $0.95(0.91-0.98)$ & $0.92(0.89-0.96)$ \\
\hline & $45-54$,years & 9,176 & 9.5 & 8,830 & 10.5 & $0.93(0.90-0.97)$ & $0.91(0.88-0.95)$ \\
\hline & $55-64$,years & 1,904 & 2.0 & 1,836 & 2.2 & $0.93(0.87-1.00)$ & $0.94(0.87-1.02)$ \\
\hline & $65-74$, years & 461 & 0.5 & 343 & 0.4 & $1.21(1.05-1.39)$ & $1.20(1.05-1.44)$ \\
\hline & 75 ,years, and,over & 123 & 0.1 & 88 & 0.1 & $1.26(0.95-1.65)$ & $1.48(1.10-1.99)$ \\
\hline & Not,known & 572 & 0.6 & 370 & 0.4 & $1.39(1.22-1.59)$ & $1.01(0.87-1.18)$ \\
\hline \multirow[t]{3}{*}{ Helmeted } & Yes & 85,731 & 88.5 & 75,122 & 89.1 & 1 & \\
\hline & No & 1,904 & 2.0 & 840 & 1.0 & $1.97(1.83-2.15)$ & $1.55(1.41-1.71)$ \\
\hline & Not,known & 9,272 & 9.6 & 8,359 & 9.9 & $0.97(0.94-1.00)$ & $1.04(1.00-1.07)$ \\
\hline Blood alcohol & Not,found & 16,152 & 16.7 & 14,282 & 16.9 & 1.07 (1.04-1.09) & $1.07(1.03-1.10)$ \\
\hline \multirow[t]{6}{*}{ level } & Found,,result,unknown & 12,931 & 13.3 & 10,777 & 12.8 & $1.13(1.10-1.16)$ & $1.09(1.03-1.15)$ \\
\hline & $<0,5, \mathrm{~g} / \mathrm{l}$ & 62,422 & 64.4 & 58,836 & 69.8 & 1 & \\
\hline & {$[0,5-0,8[\mathrm{~g} / \mathrm{l}$} & 540 & 0.6 & 117 & 0.1 & $4.35(3.56-5.31)$ & $3.74(3.01-4.63)$ \\
\hline & {$[0,8-1,2[\mathrm{~g} / \mathrm{l}$} & 1,000 & 1.0 & 99 & 0.1 & $9.52(7.74-11.7)$ & $7.37(5.94-9.16)$ \\
\hline & {$[1,2-2,0[\mathrm{~g} / \mathrm{l}$} & 2,184 & 2.3 & 133 & 0.2 & $15.5(13.0-18.4)$ & $9.75(8.11-11.7)$ \\
\hline & $2, \mathrm{~g} / \mathrm{l}, \mathrm{et},+$ & 1,678 & 1.7 & 77 & 0.1 & $20.5(16.3-25.7)$ & $11.4(9.01-14.5)$ \\
\hline Validity of & Not,known & 3,124 & 3.2 & 2,462 & 2.9 & $1.09(1.03-1.15)$ & $1.00(0.94-1.07)$ \\
\hline \multirow[t]{5}{*}{ driving licence } & Not,valid & 4,295 & 4.4 & 1,493 & 1.8 & $2.46(2.31-2.62)$ & $2.04(1.91-2.19)$ \\
\hline & Valid,,time,held,not,known & 5,198 & 5.4 & 4,142 & 4.9 & $1.07(1.03-1.13)$ & $1.04(0.99-1.09)$ \\
\hline & $\begin{array}{l}\text { Valid, } \\
\text { held,for<2,years }\end{array}$ & 24,326 & 25.1 & 20,818 & 24.7 & 1 & \\
\hline & $\begin{array}{l}\text { Valid,, } \\
\text { held,for,[2-5[,years }\end{array}$ & 19,910 & 20.5 & 17,871 & 21.2 & $0.95(0.93-0.98)$ & $0.97(0.94-1.00)$ \\
\hline & $\begin{array}{l}\text { Valid, } \\
\text { held,for, } \geq 5 \text { years }\end{array}$ & 40,054 & 41.3 & 37,535 & 44.5 & $0.91(0.89-0.93)$ & $0.97(0.94-1.00)$ \\
\hline \multirow[t]{6}{*}{ Trip purpose } & Home-to-work & 17,958 & 18.5 & 18,456 & 21.9 & $0.78(0.76-0.80)$ & $0.90(0.88-0.93)$ \\
\hline & Home-to-school & 749 & 0.8 & 777 & 0.9 & $0.73(0.66-0.81)$ & $0.84(0.75-0.94)$ \\
\hline & Leisure & 49,159 & 50.7 & 37,397 & 44.4 & 1 & \\
\hline & Other & 16,962 & 17.5 & 15,410 & 18.3 & $0.84(0.82-0.86)$ & $1.02(0.99-1.05)$ \\
\hline & At,work & 10,043 & 10.4 & 10,481 & 12.4 & $0.73(0.71-0.75)$ & $0.98(0.94-1.01)$ \\
\hline & Not,known & 2,036 & 2.1 & 1,800 & 2.1 & $0.86(0.81-0.92)$ & $0.96(0.89-1.04)$ \\
\hline Number of & None & 84,607 & 87.3 & 74,320 & 88.1 & 1 & \\
\hline passengers & 1, or,more & 12,300 & 12.7 & 10,001 & 11.9 & $1.08(1.05-1.11)$ & $0.92(0.89-0.95)$ \\
\hline
\end{tabular}

${ }^{a}$ Analyses adjusted for the time of day, the day, the month and the year of the accident, and the location, type of road and type of accident. 


\section{Discussion}

We have analyzed the association between the rider related factors and the risk of being responsible for an injury accident. A number of our findings merit discussion.

First, we found the factor with the strongest association with accident responsibility to be alcohol consumption: we identified an increase in the risk of injury accidents after alcohol consumption, with a dose effect. Two other studies have measured this association among PTW riders and also found an increase in the risk of responsibility (Lardelli-Claret et al. 2005; Williams et al. 1985).

In common with the majority of studies, we identified an excess risk of accident involvement among novice PTW riders (Chang and Yeh 2006; Evans 2004; Harrison and Christie 2005; Lardelli-Claret et al. 2005; Lin et al. 2003; Mullin et al. 2000; Reeder et al. 1995; Rutter and Quine 1996; Ryan et al. 1998; Skalkidou et al. 1999; Yannis et al. 2005). This may be due to a combination of young people's inexperience and risk-taking (Chesham et al. 1993; Ryan et al. 1998) as well as risk exposure (Harrison and Christie 2005; Yannis et al. 2005). We also identified an increased accident risk for the oldest riders, in common with another study (Lardelli-Claret et al. 2005). The high accident rate among the oldest riders may be explained by an age-related reduction in their driving skill and by the difficulty they experience in dealing with complex driving situations (Lardelli-Claret et al. 2005; Ryan et al. 1998).

With regard to rider gender, we identified an excess accident risk among men compared with women, as has already been mentioned in other studies (Lardelli-Claret et al. 2005; Lin et al. 2003). Their riskier behaviours mean that men are more often involved in injury accidents. The higher injury accident risk among male riders may also be explained by the fact that this risk is very strongly linked to speed (Fergusson et al. 2003).

Among the motorcycle riders, we have found that those riders without a valid licence had an increased risk of accident involvement. This has also been observed in other studies (Haworth and Schulze 1996; Hurt et al. 1981; Lardelli-Claret et al. 2005; Lin et al. 2003; Magazzu et al. 2006; Reeder et al. 1999; Rutter and Quine 1996; Wells et al. 2004). With regard to driving experience, which we measured on the basis of the length of time the riders had held their licence, we found that novice riders (who had held their licence for less than 2 years) had a higher accident involvement risk than riders who had done so for more than 2 years. This result concurs with other studies (Harrison and Christie 2005; Lardelli-Claret et al. 2005; Lin et al. 2003; Mullin et al. 2000).

Our study, which has been adjusted both for age and experience, allows us to estimate the specific effects of these factors. After adjustment for both, the effects of these two factors remain significant.

We found that riders who used their moped or motorcycle for leisure trips had a higher risk of accident involvement than during home-to-work trips, home-to-school trips or trips made while at work. Other studies have identified an increased accident risk during leisure trips, and not only among PTW users (Chiron et al. 2008; Gregersen and Berg 1994). During leisure trips, ignorance of the route increases the risk of PTWs being caught unawares by a defect in the road, for example 
poor surface condition. A second hypothesis relates to differences in driving behaviour between a rider travelling to work and a rider travelling for leisure purposes.

One difference between moped and motorcycle riders related to the effect of carrying a passenger on the vehicle: while a passenger increased the risk of accident involvement among moped users, it reduces this risk among motorcycle riders. The lower accident risk when carrying a passenger among motorcycle riders may be explained by trip purpose and more cautious behaviour when they have a passenger. However, for moped users, carrying a passenger is illegal in most cases, except when the vehicle is equipped for the purpose. Carrying a passenger on a moped is therefore an indicator of non compliance with regulations, which itself is an indicator of risk-taking. The literature contains two studies that investigated the carrying of a passenger on a PTW. The study by Lardelli et al. also highlighted the protective effect of carrying a passenger on a motorcycle, and also did so for mopeds (Lardelli-Claret et al. 2005). However, another study has shown an increase in accident risk when carrying a passenger on a motorcycle (Quddus et al. 2002).

This study analyzed national data from the police concerning a large number of PTW riders involved in injury accidents of all levels of severity. We studied the rider's responsibility for the accident, a criterion which is often used in case-control studies in transportation epidemiology: we compared distributions of the main characteristics of the accident-involved PTW riders according to whether they were responsible or not for the accident. In this way, we substituted accident risk exposure (a comparison of factors between riders who have had an accident and riders who have not) for exposure to the risk of being responsible for the accident (a comparison of factors between riders who are responsible and riders who are not). The criterion of responsibility provides a way of identifying non-responsible riders who were involved in an accident as a result of "bad luck", just because they happened to be on the road at the time. If we make the hypothesis that these controls are representative of the riders on the road, our analysis amounts to estimating the risk of one of the PTW riders on the road being responsible for an accident. This hypothesis has been validated in a previous study using the same methodology, but dealing with all drivers involved in fatal accidents (Laumon et al. 2005). This validation is less easy to conduct on our PTW sample, as no estimation from PTW population survey was available concerning, for example, the proportion of riders on the road with blood alcohol level above the legal limit. Anyway if, in spite of adjustments for many factors, controls are too close to cases, this would lead to underestimation of odds ratios. This does not rule out the significant risk factors found. Otherwise, as the studied event is rare (one individual out of those on the road being responsible for an injury accident) the estimated odds ratios for responsibility for each factor are good estimations of the corresponding relative risks.

The large number of subjects in the study meant we were able to explore the dose-effect association between factors such as alcohol and accident risk. By separating moped riders from motorcycle riders, we anticipated differences between the two types of vehicles, the populations that use them and how they are used.

Responsibility analysis (Robertson and Drummer 1994) has already been used by other research groups, validated by a group of experts and adapted to the BAAC data (Laumon et al. 
2005). All PTW riders are eligible, irrespective of the type of accident they were involved in, including single PTW accidents. In the latter case, as there is just one rider, the percentage of responsible riders was very high (91.5\%). As responsibility analysis takes account of the traffic conditions at the time of the accident, it allowed the rider to be classified as non responsible in $8.5 \%$ of the single PTW accidents: a number of factors such as poor weather conditions, a faulty vehicle, performing an avoidance manoeuvre, or a collision with an animal affected the responsibility score.

Speed is a major accident risk factor for PTWs and no further proof is required of its influence on accident occurrence (Lardelli-Claret et al. 2005; Shankar et al. 1992). The BAAC only contains speed data when there has been a speed violation. The police statement concerning responsibility for the accident may also implicitly take account of speed. Adjustment of the analyses for the type of road, which is on average correlated with the speed, allows us to take account of speed in an indirect manner. Speed violations and responsibility ascribed by the police are used to calculate the responsibility score, which means that speed cannot be considered as an explanatory factor. A possible alternative would be to use a reported speed violation to measure speed and consider it as the variable of interest. However, the BAAC does not always provide information on excess speeding and this is implicitly taken into account when the police make their statement of responsibility. Consequently, it was not impossible for us to exclude speed completely when calculating the responsibility score.

Although we were unable to study speed as a factor of interest, we were able to do this with alcohol consumption. This factor may influence the determination of responsibility as drink-driving is a violation and if the police suspect alcohol consumption they may state the rider was responsible for the accident. If the responsibility analysis meant that those riders who had consumed alcohol were classified as responsible, our study would present a differential classification bias leading to an overestimation of alcohol-related risk. To avoid this, our responsibility analysis did not consider the alcohol violation codes. However, even if the police officers did not know the results of the alcohol test performed on the rider, we cannot exclude the possibility that they presumed the rider to be responsible because they suspected alcohol consumption. Nevertheless, our estimated odds ratios with regard to alcohol lie within the same range as those recently published by Lardelli et al. (Lardelli-Claret et al. 2005), which confirms the validity of our findings.

To conclude, this study has enabled us to identify the major excess risk factors for injury accidents among PTW riders, and above all to quantify their effects. This study suggests that road safety and public health programmes may reduce the number of PTW accidents as the majority of the factors that have been identified in the study are factors which are amenable to modification by prevention activities or regulations. 


\section{References}

Chandraratna, S. and Stamatiadis, N., 2009. Quasi-induced exposure method: evaluation of not-at-fault assumption. Accid Anal Prev 41 (2), 308-313.

Chang, H. L. and Yeh, T. H., 2006. Risk factors to driver fatalities in single-vehicle crashes: comparisons between non-motorcycle drivers and motorcyclists. journal of transportation engineering 132 (3), 227236.

Chesham, D. J., Rutter, D. R. and Quine, L., 1993. Motorcycling safety research: a review of the social and behavioral literature. Soc Sci Med 37 (3), 419-429.

Chiron, M., Bernard, M., Lafont, S. and Lagarde, E., 2008. Tiring job and work related injury road crashes in the GAZEL cohort. Accid Anal Prev 40 (3), 1096-1104.

Evans, L., 2004. Traffic Safety. New-York: Bloomfield Hills, Science Serving Society.

Fergusson, D., Swain-Campbell, N. and Horwood, J., 2003. Risky driving behaviour in young people: prevalence, personal characteristics and traffic accidents. Aust N Z J Public Health 27 (3), 337-342.

Gregersen, N. P. and Berg, H. Y., 1994. Lifestyle and accidents among young drivers. Accid Anal Prev 26 (3), 297-303.

Harrison, W. A. and Christie, R., 2005. Exposure survey of motorcyclists in New South Wales. Accid Anal Prev 37 (3), 441-451.

Haworth, N. L. and Schulze, M. T., 1996. Motorcycle crash countermeasures: literature review and implementation workshop. Monash University Accident Research Center.

Horswill, M. S. and Helman, S., 2003. A behavioral comparison between motorcyclists and a matched group of non-motorcycling car drivers: factors influencing accident risk. Accid Anal Prev 35 (4), 589-597.

Hurt, H. H., Ouellet, J. V. and Thom, D. R., 1981. Motorcycle accident cause factors and identification of countermeasures, Volume 1: Technical Report. Los Angeles: Traffic Safety Center, University of Southern California.

Langley, J., Mullin, B., Jackson, R. and Norton, R., 2000. Motorcycle engine size and risk of moderate to fatal injury from a motorcycle crash. Accid Anal Prev 32 (5), 659-663.

Lardelli-Claret, P., Jimenez-Moleon, J. J., de Dios Luna-del-Castillo, J., Garcia-Martin, M., Bueno-Cavanillas, A. and Galvez-Vargas, R., 2005. Driver dependent factors and the risk of causing a collision for two wheeled motor vehicles. Inj Prev 11 (4), 225-231.

Laumon, B., Gadegbeku, B., Martin, J. L. and Biecheler, M. B., 2005. Cannabis intoxication and fatal road crashes in France: population based case-control study. Bmj 331 (7529), 1371.

Laumon, B., Gadegbeku, B., Martin, J. L. and group, t. S., 2009. Stupéfiants et accidents mortels de la circulation routière: analyse épidémiologique. Paris: OFDT, ed.

Lin, M. R., Chang, S. H., Pai, L. and Keyl, P. M., 2003. A longitudinal study of risk factors for motorcycle crashes among junior college students in Taiwan. Accid Anal Prev 35 (2), 243-252.

Magazzu, D., Comelli, M. and Marinoni, A., 2006. Are car drivers holding a motorcycle licence less responsible for motorcycle--car crash occurrence? A non-parametric approach. Accid Anal Prev 38 (2), 365-370.

Mullin, B., Jackson, R., Langley, J. and Norton, R., 2000. Increasing age and experience: are both protective against motorcycle injury? A case-control study. Inj Prev 6 (1), 32-35.

NHTSA, 2006. Traffic Safety Facts 2006: Motorcycles. Etats-Unis: Washington DC, Department of Transportation.

ONISR, 2007. La sécurité routière en France, bilan de l'année 2006., Paris: La Documentation Française.

Quddus, M. A., Noland, R. B. and Chin, H. C., 2002. An analysis of motorcycle injury and vehicle damage severity using ordered probit models. J Safety Res 33 (4), 445-462.

Reeder, A. I., Alsop, J. C., Langley, J. D. and Wagenaar, A. C., 1999. An evaluation of the general effect of the New Zealand graduated driver licensing system on motorcycle traffic crash hospitalisations. Accid Anal Prev 31 (6), 651-661.

Reeder, A. I., Chalmers, D. J. and Langley, J. D., 1995. Young on-road motorcyclists in New Zealand: age of licensure, unlicensed riding, and motorcycle borrowing. Inj Prev 1 (2), 103-108. 
Robertson, M. D. and Drummer, O. H., 1994. Responsibility analysis: a methodology to study the effects of drugs in driving. Accid Anal Prev 26 (2), 243-247.

Rutter, D. R. and Quine, L., 1996. Age and experience in motorcycling safety. Accid Anal Prev 28 (1), 15-21.

Ryan, G. A., Legge, M. and Rosman, D., 1998. Age related changes in drivers' crash risk and crash type. Accid Anal Prev 30 (3), 379-387.

SafetyNet, 2008. Traffic safety basic facts 2008, motorcycles and mopeds., Loughborough European Road Safety Observatory (ERSO).

Shankar, B. S., Ramzy, A. I., Soderstrom, C. A., Dischinger, P. C. and Clark, C. C., 1992. Helmet use, patterns of injury, medical outcome, and costs among motorcycle drivers in Maryland. Accid Anal Prev 24 (4), 385-396.

Skalkidou, A., Petridou, E., Papadopoulos, F. C., Dessypris, N. and Trichopoulos, D., 1999. Factors affecting motorcycle helmet use in the population of Greater Athens, Greece. Inj Prev 5 (4), 264-267.

Wells, S., Mullin, B., Norton, R., Langley, J., Connor, J., Lay-Yee, R. and Jackson, R., 2004. Motorcycle rider conspicuity and crash related injury: case-control study. Bmj 328 (7444), 857.

Williams, A. F., Peat, M. A., Crouch, D. J., Wells, J. K. and Finkle, B. S., 1985. Drugs in fatally injured young male drivers. Public Health Rep 100 (1), 19-25.

Yannis, G., Golias, J. and Papadimitriou, E., 2005. Driver age and vehicle engine size effects on fault and severity in young motorcyclists accidents. Accid Anal Prev 37 (2), 327-333. 